\title{
FUNCTIONAL COMPOSITION OF BENTHIC MACROINVERTEBRATE FAUNA IN THE PLATEAU RIVERS, BUNDELKHAND, CENTRAL INDIA
}

\author{
Asheesh Shivam Mishra ${ }^{1}$ \& Prakash Nautiyal $^{2}$ \\ ${ }^{1,2}$ Aquatic Biodiversity Unit, Department of Zoology \& Biotechnology, Hemvati Nandan Bahuguna Garhwal University \\ (A Central University), Srinagar, Garhwal, Uttarakhand 246174, India \\ ${ }^{1}$ shivam_a2000@yahoo.co.in (corresponding author), ${ }^{2}$ lotic.biodiversity@gmail.com
}

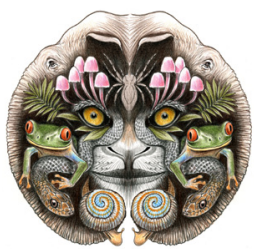

ISSN

Online 0974-7907

Print 0974-7893

OPEN ACCESS
Abstract: The functional organization of benthic macroinvertebrate fauna was studied in two central Indian rivers of Bundelkhand region, the Ken and Tons. Both the rivers are approximately $320 \mathrm{~km}$ from source to mouth. The taxonomic richness in both the rivers decreased in the mouth zone of the river. Functionally, both rivers were in heterotrophic state from headwater to mouth, as share of collectors among other functional groups was high all along the river. However, the share of collectors decreased from the headwater to mouth in both the rivers, while scrapers and predators increased in the Ken but no trend was evident in the Tons.

Keywords:, Bundelkhand, central highlands, collectors, heterotrophic state, Vindhya.

Changes in food availability play an important role in the distribution of functional groups along a watercourse, as well as in seasonal changes of the biocenosis (Allan 1995). The relations among functional groups are often more important for community description than taxonomic status of organisms. Classification according to functional groups provides a further perspective that can be combined with the other community attributes to ensure a better understanding of the match between habitat and aquatic fauna (Towsend et al. 1997). Benthic macroinvertebrate fauna is used to determine the functional status of the rivers/streams in various parts of the world: North America and Europe (Hawkins \& Sedell 1981; Ramusino et al. 1995; Grubaugh et al. 1996; RosiMarshall \& Wallace 2002; Hernandez et al. 2005), South America (Fernandez \& Domin-quez 2001; Callisto et al. 2001; Cummins et al. 2005) and Asia (Hu et al. 2005; Yan \& Li 2006; Jiang et al. 2011).

However, in South Asia especially in India some knowledge regarding the functional organisation of benthic macroinvertebrates is available from the Western Ghats (Sivaramakrishnan 1992; Burton \& Sivaramakrishnan 1993; Sivaramakrishnan et al. 1996; Subramanian \& Sivaramakrishnan 2005), but is limited in the Himalaya (Nautiyal 2010; Bhatt \& Pandit 2010) and the central highlands (central India) (Mishra \& Nautiyal 2011). In light of the above, a study was organised in two $3^{\text {rd }}$ order streams of the central highlands ecoregion to describe the taxonomic richness and functional feeding groups of the macroinvertebrate community and how it changes along the longitudinal gradient in the agriculturally impacted rivers.

DOI: http://dx.doi.org/10.11609/JoTT.o3226.4752-8 | ZooBank: urn:Isid:zoobank.org:pub:5C5EB3F5-C86C-4DA9-83B9-2D6CA63E8DDD

Citation: Asheesh Shivam Mishra \& Prakash Nautiyal (2013). Functional composition of benthic macroinvertebrate fauna in the plateau rivers, Bundelkhand, central India. Journal of Threatened Taxa 5(13): 4752-4758; http://dx.doi.org/10.11609/JoTT.03226.4752-8

Copyright: ( Mishra \& Nautiyal 2013. Creative Commons Attribution 3.0 Unported License. JoTT allows unrestricted use of this article in any medium, reproduction and distribution by providing adequate credit to the authors and the source of publication.

Funding: The present study was conducted with the financial support given by University of Allahabad during DPhil Degree programme of the first author (ASM).

Competing Interest: Authors declare no competing interest.
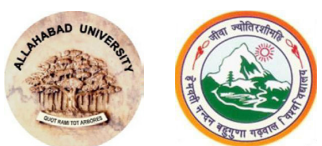

Acknowledgements: The academic supports by Head, Department of Zoology and Biotechnology, H.N.B. Garhwal University and University of Allahabad, is acknowledged. The first author (ASM) is thankful to U.G.C., New Delhi for providing fellowship during the D. Phil. programme. 


\section{Methods}

\section{Study Area}

The rivers Ken and Tons originate approximately at an elevation of $400 \mathrm{~m}$ from the Kaimur series of the Upper Vindhyan range (central India), and flow north through Bundelkhand plateau to meet the Yamuna at Chilla at an elevation of $86 \mathrm{~m}$ and the Ganga at Sirsa near Allahabad at $72 \mathrm{~m}$ in the Gangetic plain, respectively (Table1). Agriculture is a major landuse along with the Panna National Park and human habitation (village, town and city) at sampling stations (Table 1; Fig.1). The sampling stations were selected on the basis of similarity in the physiographic conditions between these two rivers (viz., distance from the source, altitude, latitude, substrate type) and stream orders (http://creekconnections. allegheny.edu). The scale of investigation, accessibility, costs and benefits of the sampling programme (Sheldon 1984; Table 1) were also key factors in the selection of the sampling locations.

\section{Sampling rationale}

The benthic macroinvertebrate fauna were collected at four stations in each river from December 2003 to March 2004 (Table 1) in order to generate information on the functional distribution of macroinvertebrates in the Ken and Tons rivers. Each station was sampled once during the above-said period. One-time intensive sampling in the dry-period was considered appropriate for such studies (Corkum 1989, 1991). The dry-period extends from October to June but sampling was restricted to only the above-said period because long

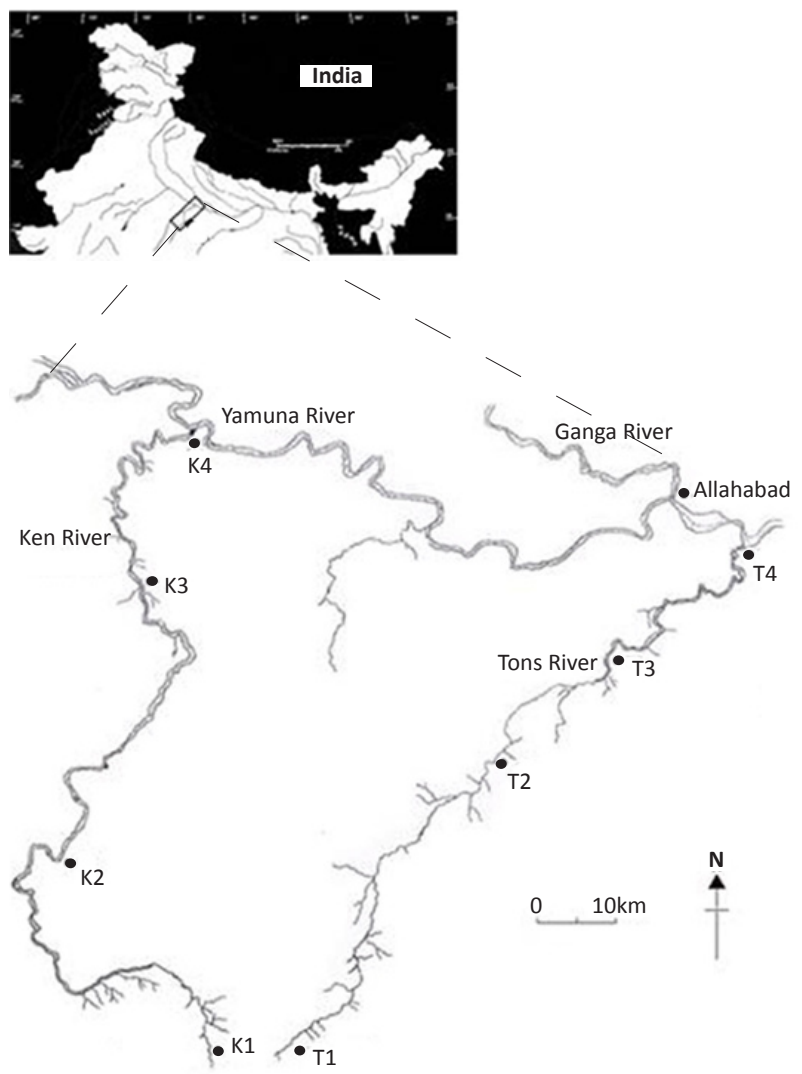

Figure 1. Location of the Ken and Tons rivers in India and sampling stations (K1 to K4 and T1 to T4) selected for the study.

stretches of the river tend to dry up during the summer season (March to June), forming pools of various sizes and thus disrupting the continuum. There is a focus on the dry period because it accounts for a major part of the year (nine months) compared to the wet period (three

Table 1. Geographical coordinates of the sampling locations along with physico-chemical characteristics, landuse, and taxonomic richness.

\begin{tabular}{|c|c|c|c|c|c|c|c|c|}
\hline \multirow{2}{*}{$\begin{array}{l}\text { River } \\
\text { Station }\end{array}$} & \multicolumn{4}{|c|}{ Ken } & \multicolumn{4}{|c|}{ Tons } \\
\hline & K1 & K2 & K3 & K4 & T1 & T2 & T3 & T4 \\
\hline Latitude $\left({ }^{\circ} \mathrm{N}\right)$ & $23^{0} 59^{\prime}$ & $24^{\circ} 44^{\prime}$ & $25^{0} 28^{\prime}$ & $25^{\circ} 46^{\prime}$ & $24^{0} 16^{\prime}$ & $24^{0} 33^{\prime}$ & $25^{\circ} 02^{\prime}$ & $25^{\circ} 16^{\prime}$ \\
\hline Longitude $\left({ }^{\circ} \mathrm{E}\right)$ & $80^{\circ} 18^{\prime}$ & $80^{\circ} 41^{\prime}$ & $80^{\circ} 18^{\prime}$ & $80^{\circ} 31^{\prime}$ & $80^{\circ} 48^{\prime}$ & $80^{\circ} 54^{\prime}$ & $81^{\circ} 43^{\prime}$ & $82^{\circ} 04^{\prime}$ \\
\hline Altitude m (asl) & 365 & 200 & 95 & 86 & 326 & 290 & 94 & 72 \\
\hline Land use & $A g-V$ & $\mathrm{Ag}-\mathrm{F}$ & $\mathrm{Ag}-\mathrm{C}$ & $\mathrm{Ag}$ & $\mathrm{Ag}-\mathrm{V}$ & $\mathrm{Ag}-\mathrm{V}$ & $\mathrm{Ag}-\mathrm{T} / \mathrm{V}$ & $\mathrm{Ag}$ \\
\hline $\begin{array}{l}\text { Substrate } \\
\text { Type }\end{array}$ & $\mathrm{R}>\mathrm{C}>\mathrm{P}>\mathrm{Si}$ & $\mathrm{R}>\mathrm{C}>\mathrm{P}>\mathrm{S}>\mathrm{Si}$ & $\mathrm{R}>\mathrm{C}>\mathrm{P}>\mathrm{G}>\mathrm{S}$ & $\mathrm{Cl}>\mathrm{Si}$ & $\mathrm{B}>\mathrm{C}>\mathrm{P}>\mathrm{S}$ & $\mathrm{C}>\mathrm{P}>\mathrm{G}>\mathrm{S}>\mathrm{B}$ & $\mathrm{C}>\mathrm{P}>\mathrm{B}>\mathrm{R}>\mathrm{G}>\mathrm{S}$ & $\mathrm{Cl}-\mathrm{Si}$ \\
\hline $\begin{array}{l}\text { Range water } \\
\text { temperature }\left({ }^{\circ} \mathrm{C}\right)\end{array}$ & $15-21.5$ & $16-22$ & $17-24.5$ & $20.5-27$ & $17-30$ & $17.5-28$ & $17-27$ & $17-24.0$ \\
\hline $\begin{array}{l}\text { Range current } \\
\text { velocity }\left(\mathrm{cms}^{-1}\right)\end{array}$ & 1.0 & $10-60$ & $2.0-12$ & 1.0 & $0-30.8$ & $1.6-4.8$ & $1.5-15$ & $<0.1$ \\
\hline $\mathrm{pH}$ & $7.2-7.5$ & $7.0-7.2$ & $7.2-7.5$ & $7.2-7.5$ & $7.0-7.6$ & $7.4-7.6$ & $7.4-7.6$ & $7.5-7.8$ \\
\hline Stream Order & 2 & 3 & 3 & 3 & 1 & 2 & 2 & 3 \\
\hline Taxonomic Richness & 12 & 15 & 14 & 12 & 19 & 16 & 19 & 11 \\
\hline
\end{tabular}

$\mathrm{Ag}$ - agriculture, C - city, F - corest, T - town, V - village, C - cobble, P - pebble, B - boulder, R - rock, G - gravel, S - sand, Si - silt, Cl - clay. 
months) due to the monsoon from July to September (Unni 1996; Vombatkere 2005). The composition of macroinvertebrate fauna remain relatively stable in the dry period than during the floods (Jüttner et al. 2003). The floods replenish nutrients and particulate organic matter in the river, which sustain the food chains and thus these communities.

The water temperature was recorded with the help of a digital temperature probe and $\mathrm{pH}$ through a digital $\mathrm{pH}$ meter. Current velocity was measured with the help of the float method (Welch 2003). The substrate was categorized by measuring the substrate particle size (Minshall 1984). Intensive sampling (20 quadrates of $0.09 \mathrm{~m}^{2}$ each) was performed at each station to cover all the possible microhabitats available within 200m up and downstream of the river. Lifting of stony substrates (boulder, cobble, pebble, gravel) and sieving of soft substrate (sand, silt, and clay) were adopted to collect benthic macroinvertebrate samples. The substratum in the form of small boulders, cobbles and pebbles were lifted carefully from the marked area and washed in a bucket full of water by dipping it a number of times to dislodge the attached fauna. The fauna that remained attached to the substrate surface were removed with the help of a brush. The bucket water was filtered through a $0.05 \mathrm{~mm}$ sieve to retain benthic macroinvertebrate fauna (Singh \& Nautiyal 1990; Habdija et al. 1997).

The retained samples were preserved in $4 \%$ formalin for further analysis. Various benthic taxa were identified to family level with the help of different keys (Pennak 1953; Edmondson 1959; Edington \& Hildrew 1995; Nesemann et al. 2004). The family level studies have been successfully used to describe biogeographical patterns across large areas (Corkum 1989). Family level identification is used to determine the functional feeding group (FFG) in the rivers (Ramusino et al. 1995; Merritt \& Cummins 1996; Cummins et al. 2005). The functional classification of invertebrate fauna depends on the feeding habits (Table 2 ). A relative abundance of various taxa at the above stated sites was computed as a percentage of the total benthic macroinvertebrate count from 20 quadrates to determine the functional feeding groups. Functional similarity among the stations between these two rivers was determined from the relative abundance by cluster analysis (Ward's methods, PAST; http://nhm2.uio.no/norlex/past/download.html).

\section{Results}

In both the rivers, the water temperature and $\mathrm{pH}$ increased while current velocity decreased from upper to mouth zone (Table 1). A total of 24 taxa belonging to three phyla were recorded: Annelida, Arthropoda and Mollusca. Arthropoda contributed to a maximum of 19 macroinvertebrate taxa in the community, while Annelida contributed to three followed by Mollusca (2) (Table 3). A general increase in the taxonomic richness was observed in the Ken from K1 to K3 while no change was observed from $\mathrm{T} 1$ to $\mathrm{T} 3$ except a relative decline at $\mathrm{T} 2$ (16). However, least richness was observed at K4 and T4 (Table 1). Neoephemeridae, Caenidae, Leptophlebiidae and Thiaridae were the most abundant taxa at K1, K2, K3 and K4, respectively. However, Thiaridae was the most abundant taxa at all stations in the Tons except at T3 where Neoephemeridae was abundant (Table 3). Collectors were the most abundant functional feeding group at all stations in both the rivers except at $\mathrm{T} 2$. The relative share of collectors decreased, while scrapers and predators increased in the Ken River (Fig. 2). However, no trend (neither an increase nor a decrease) was observed in the Tons River (Fig. 3). Cluster analysis indicated functional similarity in the lower zone (K3-T3) and mouth zone (K4-T4) of both the rivers (Fig.4)

Table 2. Functional group characterization and food resources (from Merritt \& Cummis 1996b).

\begin{tabular}{|l|l|l|l|}
\hline Type of FFG & Particle size feeding mechanism & Dominant food resources & $\begin{array}{l}\text { Range of particle } \\
\text { size of food (mm) }\end{array}$ \\
\hline Shredders & $\begin{array}{l}\text { Chew conditioned litter or live vascular plants tissue, or } \\
\text { gouge wood }\end{array}$ & $\begin{array}{l}\text { CPOM - decomposing (or living hydrophytes) vascular } \\
\text { plants }\end{array}$ & $>1.0$ \\
\hline $\begin{array}{l}\text { Filtering } \\
\text { collectors }\end{array}$ & Suspension feeders-filter particles from water column & $\begin{array}{l}\text { FPOM-decomposing detrital particles; algae, bacteria } \\
\text { and feces }\end{array}$ & $0.01-1.0$ \\
\hline $\begin{array}{l}\text { Gathering } \\
\text { collectors }\end{array}$ & $\begin{array}{l}\text { Deposits feeders-ingest sediments or gather loose particles } \\
\text { in depositional areas }\end{array}$ & $\begin{array}{l}\text { FPOM- decomposing detrital particles; algae, bacteria } \\
\text { and feces }\end{array}$ & $\begin{array}{l}\text { Periphyton attached non-filamentous algae and } \\
\text { associated detritus, microflora, fauna and feces }\end{array}$ \\
\hline Scraper & $\begin{array}{l}\text { Graze rock and wood surfaces or stems of rooted aquatic } \\
\text { plants }\end{array}$ & Prey- living animal & $>0.01-1.0$ \\
\hline Predators & Capture and engulf prey or tissue, ingest body fluids & $\mathbf{2 0 . 5}$ \\
\hline
\end{tabular}

FFG - Functional Feeding Group, CPOM - Coarse Particulate Organic Matter, FOPM - Fine Particulate Organic Matters. 
Table 3. Relative abundance of the taxa along with their functional feeding groups at different stations in the river Ken and Tons.

\begin{tabular}{|c|c|c|c|c|c|c|c|c|c|}
\hline \multirow{2}{*}{ Phylum*/Class + /Family } & \multirow[t]{2}{*}{ FFG } & \multicolumn{4}{|c|}{ Ken } & \multicolumn{4}{|c|}{ Tons } \\
\hline & & K1 & K2 & K3 & K4 & T1 & T2 & T3 & T4 \\
\hline Annelida*/ Oligochaetat/Glossoscolecidae & GC & 1.7 & 2.2 & - & 3.8 & 0.4 & 8.5 & 0.1 & 10.2 \\
\hline Polychaetat/Nephthydae & FC & 2.7 & 2.1 & - & 16.2 & - & 2.6 & 0.5 & 18.2 \\
\hline Hirudineat/Salifidae & $\mathrm{P}$ & - & - & - & - & 0.3 & - & 0.3 & - \\
\hline Arthropoda*/Insectat/ Leptophlebiidae & GC & - & 2.8 & 30.2 & - & 11.4 & 4.1 & 3.9 & - \\
\hline Baetidae & $\mathrm{GC}$ & 0.2 & 3.9 & 12.8 & 0.2 & 3.5 & 0.8 & 10.5 & 0.7 \\
\hline Caenidae & $\mathrm{GC}$ & 28.9 & 35.6 & 1 & 0.4 & 2.8 & 3.1 & 10.1 & 0.4 \\
\hline Neoephemeridae & $\mathrm{GC}$ & 39.7 & 25.8 & 1.4 & - & 4.8 & 17.7 & 25.6 & - \\
\hline Ephemerillidae & Sh & - & - & - & - & 1.9 & 0.5 & 9.3 & - \\
\hline Heptageniidae & Sc & - & - & - & - & 0.5 & - & 0.4 & - \\
\hline Hydroptilidae & $\mathrm{GC}$ & - & - & - & - & 18.2 & - & 0.7 & - \\
\hline Brachycentridae & FC & 0.5 & 2.8 & 7.3 & - & 15.2 & 1 & 5.1 & 0.4 \\
\hline Hydropsychidae & $\mathrm{FC}$ & - & 0.4 & 14.2 & - & 4 & 0.3 & 3.2 & - \\
\hline Glossosomatidae & FC & - & - & 1.4 & - & 0.8 & - & - & - \\
\hline Rhyacophilidae & $P$ & 1 & 1.1 & 0.3 & - & 0.6 & 6.1 & 3.3 & - \\
\hline Chironomidae & $\mathrm{GC}$ & 10.3 & 2.8 & 8.3 & 15.7 & 1 & 2.8 & 8.9 & 18.9 \\
\hline Heleidae & $\mathrm{GC}$ & 0.3 & 4.1 & 1.4 & 10.4 & 0.1 & - & 9.5 & 4.7 \\
\hline Tabanidae & $\mathrm{P}$ & - & 1.3 & - & 5.1 & 0.5 & 6.4 & 2.5 & 5.1 \\
\hline Culicidae & $\mathrm{P}$ & - & - & - & - & 0.5 & - & 0.5 & - \\
\hline Dytiscidae & $P$ & - & - & 0.3 & 4 & - & - & - & - \\
\hline Gomphidae & $\mathrm{P}$ & 0.5 & 2.4 & 11.1 & 10.4 & 0.6 & 2.5 & 1.3 & 4.7 \\
\hline Agrionidae & $\mathrm{P}$ & - & - & - & 1.5 & - & 0.5 & - & 5.1 \\
\hline Arthropoda*/Crustacea ${ }^{\dagger}$ & $\mathrm{P}$ & - & - & - & - & - & 1.1 & - & - \\
\hline Miscellaneous Arthropods & & 3.2 & 7.5 & 2.1 & 0.7 & 3.6 & 0.3 & 3.1 & 0.4 \\
\hline Mollusca*/Gastropodat/Thiaridae & Sc & 9.8 & 3.4 & 2.8 & 25.9 & 29.1 & 41.5 & 1.1 & 31.3 \\
\hline Pelecypodat/Corbiculidae & FC & 1.2 & 1.9 & 4.5 & 5.8 & - & - & - & - \\
\hline
\end{tabular}

GC - gathering collector, FC - filtering collector, Sh - shredder, Sc - scraper, P - predator

K1

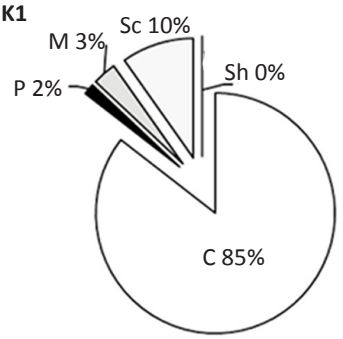

K3

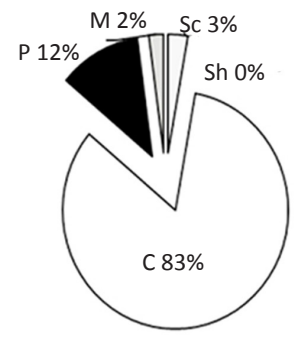

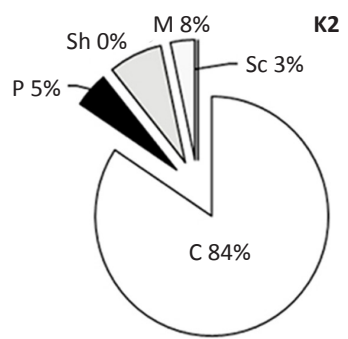

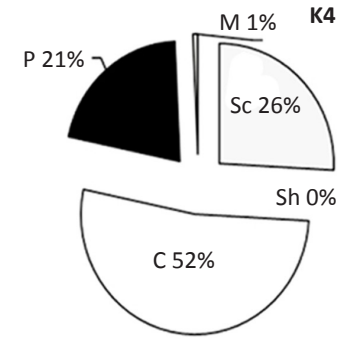

Figure 2. Percentage composition of functional feeding groups at various stations in the Ken River.

C - Collector; M - Miscellaneous; P - Predator; Sh - Shredder; Sc - Scraper
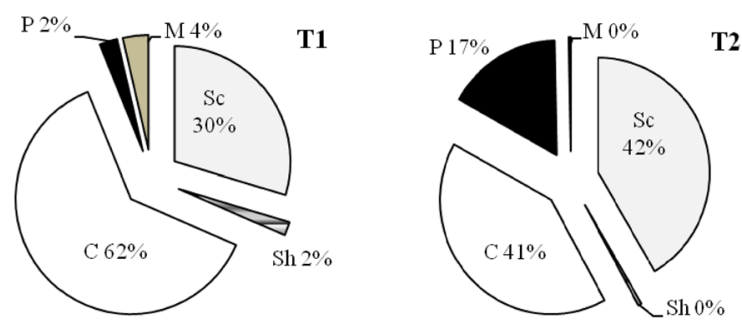

T2
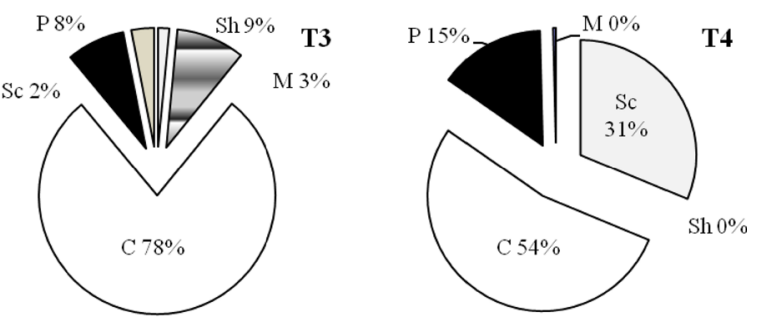

Figure 3. Percentage composition of functional feeding groups at various stations in the Tons River.

C - Collector; M - Miscellaneous; P - Predator; Sh - Shredder;

Sc - Scraper 


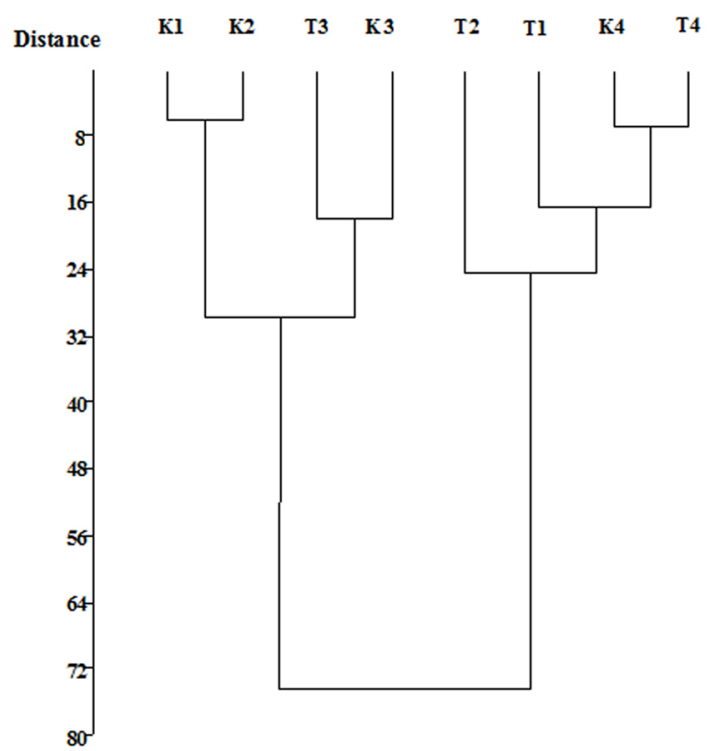

Figure 4. Cluster analysis indicated functional similarity in the lower zone (K3-T3) and mouth zone (K4-T4) of both the rivers.

\section{Discussion}

The richness of benthic macroinvertebrate fauna varied slightly in the Ken while no change was observed in the Tons from the upper to the lower sections of the rivers. The taxonomic richness decreases suddenly at the mouth section of both the rivers as the substrate becomes homogeneous as observed for the Ken (Nautiyal \& Mishra 2012). Fish species diversity is reported to decrease considerably in the lower stretches of the plateau river - Betwa in the Bundelkhand region (Lakra et al. 2010). However, the number of faunal elements was slightly high in the Tons compared to the Ken. Further, the taxonomic composition also differed in these rivers; higher relative abundance of insectsmayfly taxa (K1 to K3) except the mollusc at K4 in the Ken, compared with mollusc (except mayfly at T3) in the Tons (Table 3), attributed primarily to the difference in the substrate types, as other features differ barely (Table 1). Dytiscidae and Corbiculidae were present only in the Ken while Heptageniidae, Hydropsychidae, Hydroptilidae and Culicidae only in the Tons. These taxa are characteristic of their respective rivers. Several factors are involved in the structuring of benthic macroinvertebrate fauna: landuse (Miserendino \& Pizzolon 2003), habitat variation (riffle, runs and pool; Groff 2006) and substrate heterogeneity (Minshall 1984) are some such factors.

Functionally, both the rivers are in a heterotrophic state throughout the length, because the collectors were dominant in both the rivers at all stations excepting a slight abundance of scrapers at T2. The dominance of collectors along the river length is also known in the tropical (Miserendino \& Pizzolon 2003; Hyslop \& Hunte-Brown 2012) and subtropical rivers (Burton \& Sivaramakrishnan 1993; Jiang et al. 2011; Mishra \& Nautiyal 2011) of the world. In an Indian Himalayan river Bhagirathi collectors are known to be dominant in the headwater zone (Nautiyal 2010).

Longitudinally in the Ken and Tons collectors decrease while scrapers and predators increase marginally, as the width of the river channel decreases downstream of the river (Table 1). A similar observation was also made by Hyslop \& Hunte-Brown (2012) in a Jamaica tropical river. In the Ken and Tons, the percentage of scrapers increased with the increase in algal production (periphyton) as also appears where the use of fertilisers for agriculture leads to cumulative increase in nutrient concentrations from upper to lower stretches favouring the growth of benthic algae, thus accounting for the abundance of scrapers (Stone \& Wallace 1998; Grubaugh et al. 1996). However, the longitudinal increase of predators in the downstream part was attributed to the presence of fine sediment and gentle flow (Merritt \& Cummins 1996; Schmera \& Erős 2004; Principe et al. 2010). The minute presence of shredders was noticeable at T1 and T3 in the Tons.

In natural streams the heterotrophic condition occurs due to dense riparian vegetation, while presently this condition appears due to the modification in landuse for extensive agriculture and urbanization. The Ken and Tons (1-3 stream order) are in a heterotrophic state. The River Continuum Concept (RCC; Vannote et al. 1980), categorises the streams/rivers into headwaters (orders 1-3), medium-sized streams (4-6), and large rivers $(>6)$. Since the Ken and Tons are 1-3 order rivers, they represent the headwater category. The predominance of collectors in them compared with dominance according to RCC suggests similarity in the functional feeding group (FFG) to a great extent. However, it is to be noted that the collectors in these rivers are likely to differ probably because the riparian vegetation is crop residues from agriculture compared to the forested headwaters postulated in RCC.

\section{Conclusion}

The central Indian (Highland) rivers Ken and Tons barely differ in the taxonomic richness, which is least in the mouth zone. The community structure differs among the rivers and a few taxa are restricted to either Ken or Tons. Despite structural difference, these rivers are functionally in a heterotrophic state as collectors are dominant at all stations along the length of these 
rivers. This shows functional similarity with the RCC concept to a certain extent, and also needs an in-depth examination.

\section{REFERENCES}

Allan, D.J. (1995). Stream Ecology - Structure and function of running waters. London, Weinheim, New York, Tokyo, Melbourne, Madras, Chapman and Hall, 388pp.

Bhatt, J.P. \& M.K. Pandit (2010). A macro-invertebrate based new biotic index to monitor river water quality. Current Science 96(2): 196-203.

Burton, T.M. \& K.G. Sivaramakrishnan (1993). Comparison of the insect community in the streams of the Silent valley National Park in the Southern India. Tropical Ecology 34(1): 1-16.

Callisto, M., P. Moreno \& F.A.R. Barbosa (2001). Habitat diversity and benthic functional trophic groups at Serra Do Cipo, southeast Brazil. Review Brasil Biology 61(2): 259-266.

Corkum, L.D. (1989). Patterns of benthic invertebrate assemblages in rivers of northwestern North America. Freshwater Biology 21 191-205.

Corkum, L.D. (1991). Spatial patterns of macroinvertebrate distribution along rivers in eastern deciduous forest and grassland biomes. Journal of North American Benthological Society 10(4): 358-371.

Cummins, K.W., R.W. Merritt \& P.C.N. Andeade (2005). The use of invertebrate functional groups to characterize ecosystem attributes in selected streams and rivers in south Brazil. Studies on Neotropical Fauna and Environment 40(1): 69-89; http://dx.doi. org/10.1080/01650520400025720

Edington, J.M. \& A.G. Hildrew (1995). Caseless caddis larvae of the British Isles. Freshwater Biological Association Scientific Publication 53: 1-133.

Edmondson, W.T. (1959). Freshwater Biology-2nd Edition. John Wiley and Sons, INC, New York.

Fernandez, H.R. \& E. Dominquez (editors) (2001). Guía para la determinación de los arthropodos bentónicos Sudamericanos. Serie: Investigaciones de ;a UNT; Subserie: Ciecias Exactas $y$ Naturales. Tucuman, Argentina, 282pp.

Groff, M.H. (2006). Does the River Continuum Concept Work in Small Island Streams? Functional Feeding Group Variation Along a Longitudinal Gradient. (online http://repositories.cdlib.org/wrca/ moorea/groff)

Grubaugh, J.W., J.B. Wallace \& E.S. Houston (1996). Longitudinal changes of macroinvertebrate communities along an Appalachian stream continuum. Canadian Journal of Fisheries and Aquatic Sciences 53: 896-909.

Habdija, I., I. Radanovic \& B. Primc-Habdija (1997). Longitudinal distribution of predatory benthic macroinvertebrates in a karstic river. Archiv für Hydrobiologie 139: 527-546.

Hawkins, C.P. \& J.R. Sedell (1981). Longitudinal and seasonal changes in functional organization of macroinvertebrate communities in four Oregon streams. Ecology 62: 387-397.

Hernandez, O., R.W. Merritt \& M.S. Wipfli (2005). Benthic invertebrate community structure is influenced by forest succession after clearcut logging in southeastern Alaska. Hydrobiologia 533(1-3) 45-59; http://dx.doi.org/10.1007/s10750-004-2105-6

Hu, B.J., L.F. Yang, B.X. Wang \& N. Shan (2005). Functional feeding groups ofmacroinvertebrates in 1 e6 order tributaries of the Changjiang River. Chinese Journal of Applied and Environmental Biology 11: 463-466.

Hyslop, E.J. \& M. Hunte-Brown (2012). Longitudinal variation in the composition of the benthic macroinvertebrate fauna of a typica North coast Jamaican river. Revista de Biologia Tropical 60(1): 291303.

Jiang, X., J. Xiong, Z. Xie \& Y. Chen (2011). Longitudinal patterns of macroinvertebrate functional feeding groups in a Chinese river system: A test for river continuum concept (RCC). Quaternary International 244: 289-295.

Jüttner, I., S. Sharma, B.M. Dahal \& S.J. Ormerod (2003). Diatoms as indicators of stream quality in the Kathmandu valley and middle hills of Nepal and India. Freshwater Biology 48: 2065-2084.

Lakra, W.S., U.K. Sarkar, R.S. Kumar, A. Pandey, V.K. Dubey \& O.P. Gusain (2010). Fish diversity, habitat ecology and their conservation and management issues of a tropical River in Ganga basin, India. Environmentalist 30: 306-319; http://dx.doi.org/10.1007/s10669010-9277-6.

Merritt, R.W. \& K.W. Cummins (1996). Trophic relations of macroinvertebrates, pp. 453-474. In: Hauer, F.R. \& G.A. Lamberti (eds.). Methods in Stream Ecology. Academic Press, San Diego.

Minshall, G.W. (1984). Aquatic insect-substratum relationships, pp. 388-400. In: Resh, V.H. \& D.M. Rosenberg (eds.). The Ecology of Aquatic Insects. Praeger, NewYork.

Miserendino, M.L. \& L.A. Pizzolon (2003). Distribution of macroinvertebrate assemblages in the Azul- Quemquemtreu river basin, Patagonia, Argentina. New Zealand Journal of Marine and Freshwater Research 37: 25-39.

Mishra, A.S. \& P. Nautiyal (2011). Factors governing longitudinal variation in benthic macroinvertebrate fauna of a small Vindhyan river in Central Highlands ecoregion (Central India). Tropical Ecology 52(1): 103-112.

Nautiyal, P. (2010). Food chains of Ganga River ecosystems in the Himalayas. Aquatic Ecosystem Health \& Management 13(4): 362373; http://dx.doi.org/10.1080/14634988.2010.528998

Nautiyal, P. \& A.S. Mishra (2012). Longitudinal Distribution of Benthic Macroinvertebrate Fauna in a Vindhyan River, India. International Journal of Environmental Sciences 1(3): 150-158.

Nesemann, H.G. \& R.K. Sinha (2004). Aquatic annelid (Polychaeta, Oligochaeta, Hirudinea) of the Ganga river and adjacent water bodies in Patna (India: Bihar), with description of new leech species (Family Salifidae). Annalen des Naturhistorischen Museum in Wien 105B: 139-187.

Príncipe, R.E., C.M. Gualdoni, A.M. Oberto, G.B. Raffaini \& M.C. Corigliano (2010). Spatial-temporal patterns of functional feeding groups in mountain streams of Córdoba, Argentina. Ecología Austral 20: 257-268.

Ramusino, M.C., S. Villa \& D. Calamari (1995). River continuum concept and correspondence analysis to study Alpine stream macroinvertebrate assemblage. Memorie dII'Istituto Italiano di Idrobiologia 53: 101-114.

Rosi-Marshall, E.J. \& J.B. Wallace (2002). Invertebrate food webs along a stream resource gradient. Freshwater Biology 47: 129-141.

Schmera, D \& T. Erős (2004). Effect of riverbed morphology, stream order and season on the structural and functional attributes of caddisfly assemblages. Annales de Limnologie-International Journal of Limnology 40: 193-200.

Sheldon, A.L. (1984). Cost and precision in a stream sampling program. Hydrobiologia 111: 147-152.

Singh, H.R. \& P. Nautiyal (1990). Altitudinal changes and the impact of municipal sewage on the community structure of macrobenthic insects in the torrential reaches of the river Ganges in the GarhwalHimalaya (India). Acta Hydrobiologia 32: 407-421.

Sivaramakrishnan, K.G. (1992). Composition and zonation of aquatic insect fauna of Kaveri and its tributaries and the Identification of Insect Fauna as Indicator of Pollution. D.O.E. Project Number 22/18/89-Re.

Sivaramakrishnan, K.G., G. Hannaford, J. Morgan \& V.H. Resh (1996). Biological Assessment of the Kaveri River Catchment, South India, and Using Benthic Macroinvertebrates: Applicability of Water Quality Monitoring Approaches Developed in Other Countries. International Journal of Ecology and Environmental Science 32: 113-132.

Stone, M.K. \& J.B. Wallace (1998). Long-term recovery of a mountain stream from clear cut logging: the effects of forest succession on benthic invertebrate community structure. Freshwater Biology 39: 151-169. 
Subramanian, K.A. \& K.G. Sivaramakrishnan (2005). Habitat and microhabitat distribution of stream insect communities of the Western Ghats. Current Science 89(6): 976-987.

Towsend, C.R., S. Doledec \& M.R. Scarsbrook (1997). Species traits in relation to temporal and spatial heterogeneity in streams: a test of habitat templet theory. Freshwater Biology 37: 367-387.

Unni, K.S. (1996). Ecology of River Narmada. A.P.H. Publishing Corporation, New Delhi.

Vannote, R.L., G.W. Minshall, K.W. Cummins, J.R. Sedell \& C.E. Cushing (1980). The river continuum concept. Canadian Journal of Fisheries and Aquatic Science 37: 130-137.

Vombatkere, S.G. (2005). Is linking river an answer to floods and droughts? National Water Convention 2: 228-233.

Welch, P.S. (2003). Limnological Methods. Narendra Publishing House, Delhi, 381pp.

Yan, Y.J. \& X.Y. Li (2006). Secondary production and trophic basis of five dominant chironomids in Heizhuchong Stream, Hanjiang River Basin. Journal of Lake Sciences 18: 163-171.

web source: http://creekconnections.allegheny.edu/Modules/OnineActivities/TopographicMaps/StreamOrder.pdf 